\title{
The Law Code of Simeon, Bishop of Rev-Ardashir
}

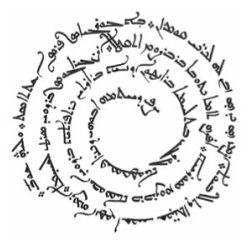




\section{Texts from Christian Late Antiquity}

Series Editor

George Anton Kiraz

TeCLA (Texts from Christian Late Antiquity) is a series presenting ancient Christian texts both in their original languages and with accompanying contemporary English translations. 


\section{The Law Code of Simeon, Bishop of Rev-Ardashir}

Edited and Translated by Amir Harrak

\footnotetext{
Gorgias

Jpress 
Gorgias Press LLC, 954 River Road, Piscataway, NJ, 08854, USA

www.gorgiaspress.com

Copyright (C) 2019 by Gorgias Press LLC

All rights reserved under International and Pan-American Copyright Conventions. No part of this publication may be reproduced, stored in a retrieval system or transmitted in any form or by any means, electronic, mechanical, photocopying, recording, scanning or otherwise without the prior written permission of Gorgias Press LLC.

2019

$$
\neg
$$

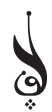

ISBN 978-1-4632-4134-6

ISSN 1935-6846

\section{Library of Congress Cataloging-in-Publication Data}

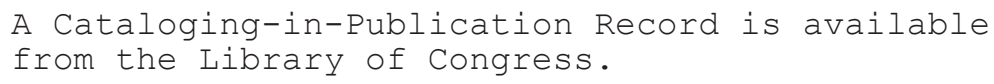

Printed in the United States of America 